\title{
PENGEMBANGAN MULTIMEDIA INTERAKTIF BERBASIS BUDAYA PADA MATA PELAJARAN MATEMATIKA
}

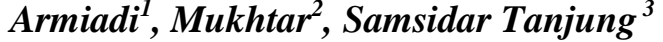 \\ ${ }^{1}$ Institut Agama Islam Negeri (IAIN) Lhokseumawe \\ ${ }^{2,3}$ Pascasarjana Universitas Negeri Medan \\ armiadi@gmail.com ${ }^{1}$
}

\begin{abstract}
Abstrak: Tujuan penelitian dan pengembangan ini adalah (1) menghasilkan media pembelajaran intaraktif berbasis budaya pada mata pelajaran matematika yang layak digunakan. (2) mengetahui efektifitas media pembelajaran intaraktif berbasis budaya pada mata pelajaran matematika. Metode pengembangan dalam penelitian ini menggunakan model pengembangan dari Thiagarajan yang lebih dikenal dengan nama model 4D, yaitu :Define (definisi), Design (Design), Develop (Pengembangan), Dissemnate (penyebaran). Hasil penelitian menunjukkan, (1) validasi ahli materi (86\%) dengan kategori sangat baik, (2) validasi ahli desain instruksional (85\%) dengan kategori sangat baik, (3) validasi ahli media pembelajaran (89\%). (4) ujicoba perorangan berada pada kualifikasi sangat baik (89\%), (5) ujicoba kelompok kecil berada pada kualifikasi sangat baik (86,3\%), (6) ujicoba lapangan berada pada kualifikasi sangat baik (81\%).Sehingga dapat disimpulkan bahwa produk pengembangan penelitian media pembelajaran interaktif berbasis budaya pada mata pelajaran matematika layak digunakan. Pada tahap penyebaran di empat sekolah berbeda menunjukkan adanya kenaikan rata-rata dari nilai pretesdan posttest yaitu dari 63,65 menjadi 86,9. Serta persentase rata-rata hasil penilaian terhadap produk multimedia interaktif berbasis budaya memburoleh nilai $83,56 \%$ dengan kriteria sangat baik. Sehingga dapat disimpulkan bahwa produk pengembangan penelitian media pembelajaran interaktif berbasis budaya pada mata pelajaran matematika sangat efektif.
\end{abstract}

Kata Kunci: pengembangan multimedia interaktif, berbasis budaya, matematika

\begin{abstract}
The objectives of this research and development are (1) to produce culture-based interactive learning media on mathematical subjects that are appropriate to be used. (2) knowing the effectiveness of culture-based interactive learning media in mathematics. The development method in this study uses a development model from Thiagarajan, better known by the name of the 4D model, namely: Define, Design, Develop, Dissemnate (deployment). The results showed, (1) the validation of material experts (86\%) with a very good category, (2) the validation of instructional design experts (85\%) with a very good category, (3) the validation of instructional media experts (89\%). (4) individual trials are in very good qualifications (89\%), (5) small group trials are in very good qualifications (86.3\%), (6) field trials are in very good qualifications (81\%). it was concluded that the product development of culture-based interactive learning media research on mathematics subjects was appropriate to use. At the stage of distribution in four different schools showed an increase in the average value of the pretest and posttest that is from 63.65 to 86.9 . And the average percentage of the results of the assessment of culture-based interactive multimedia products scored $83.56 \%$ with very good criteria. So it can be concluded that the product development of interactive culture-based learning media research in mathematics is very effective.
\end{abstract}

Keywords: interactive multimedia development, culture based, mathematics

\section{PENDAHULUAN}

Pendidikan sangat erat hubungannya dengan kebudayaan. Kebudayaan menurut Edwar Burnet Tylor, (dalam Kebudayaan adalah kompleks yang mencakup pengetahuan, kepercayaan, moral, hukum, kesenian, adatistiadat serta kebiasaan-kebiasaan yang didapatkan oleh manusia sebagai anggota dari masyarakat. Kebudayaan tersebut mencakup semua yang didapatkan atau dipelajari oleh manusia sebagai anggota masyarakat. Selain media interaktif yang digunakan berbasis budaya dalam penyampaian pembelajaran berlangsung dapat juga memvariasi pembelajaran sehingga siswa dapat mengkaitkan pembelajaran dengan kehidupan nyata.

Melalui kebudayaan yang akan digunakan adalah unsur kebudayaan aceh yang memiliki banyak unsur yang dapat dikaitkan dengan ilmu pembelajaran sehingga peserta didik dapat mempelajari ilmu pengetahuan sekaligus dapat mengenal kebudayaan sehingga dapat mengkaitkan ilmu tersebut dalam kehidupan nyata. 
Di Kabupaten aceh Timur tepatnya di SMPN 2 Indra Makmu. Proses KBM disekolah tersebut lebih dominan menggunakan metode konvensional padahal sekolah sudah memiliki berbagai fasilitas yaitu sudah tersedianya labolatorium komputer serta fasilitas lain seperti laptop atau computer, LCD dan bahkan internet. Kebanyakan siswa yang sekolah di sekolah tersebut mayoritas adalah suku Aceh. Menurut Kepala Sekolah dalam hasil wawancara dengan peneliti, siswa sangat antusias jika sekolah menyelenggarakan kegiatan kesenian budaya Aceh. Peneliti coba mengembangkan media pembelajaran pada mata pelajaran matematika yang selama ini selalu diajarkan secara ceramah yang terkesan monoton, multimedia interaktif ini nantinya akan berbentuk softwere tidak hanya menikmati hasil berupa penyajian data, tetapi juga berinteraksi secara aktif memberikan umpan balik ke dalam sistem, apalagi ilmu matematika terkenal ilmu yang banyak ditakuti peserta didik sehingga hasil belajar siswa banyak yang rendah, dengan menggunakan media interaktif dengan menggabungkan unsur budaya aceh dalam pembelajaran matematika. Penggunaan multimedia interaktif yang berbasis budaya diharapkan menyamarkan kesan sulit dalam mempelajari ilmu matematika sehingga dapat lebih meningkatkan hasil belajar.

\section{Hakikat Pembelajaran Matematika Pembelajaran Matematika}

Kata "pembelajaran" berasal dari "Instruction," istilah ini dipengaruhi oleh perkembangan teknologi yang diasumsikan dapat mempermudah siswa mempelajari segala sesuatu lewat berbagai macam media, dan guru sebagai sumber belajar menjadi guru sebagai fasilitator dalam belajar mengajar. Hal ini seperti yang diungkapkan Gagne dalam Wina Sanjaya (2008:213), yang menyatakan bahwa: "instruction is a set of event that effect learners in such a way that learning isfacilitated". Oleh karena itu menurut Gagne, mengajar atau "teaching" merupakan bagian dari pembelajaran (instruction), dimana peran guru lebih ditekankan kepada bagaimana merancang atau mengaransemen berbagai sumber dan fasilitas yang tersedia untuk digunakan atau dimanfaatkan siswa dalam mempelajari sesuatu".

\section{Keterkaitan Budaya dan Pembelajaran Matematika}

Matematika dipandang sebagai sesuatu yang jauh dari aktivitas kehidupan manusia, dan tidak terkait sama sekali dengan budaya.

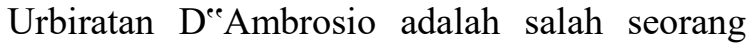
ahli pendidikan matematika yang menolak akan hal tersebut. DeeAmbrosio (2006:2) mengungkapkan bahwa matematika adalah aktor penting sekaligus tulang punggung dari peradaban manusia modern. Sejarah mencatat bahwa matematika telah terintegrasi dengan sangat baik ke dalam dunia industri, teknologi, militer, ekonomi, dan sistem politik. Melalui

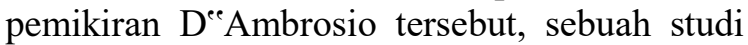
dalam pendidikan matematika kini telah dikembangkan untuk membawa proses pembelajaran ke arah yang optimal sekaligus menjaga warisan kebudayaan masyarakat.

Keberhasilan proses pembelajaran matematika dapat terjadi jika siswa memahami lingkungannya dan dirinya sendiri. Sejalan dengan itu Combs (dalam Sani, 2013:24) mengatakan bahwa yang penting dari itu adalah bagaimana membawa siswa untuk memperoleh arti bagi pribadinya dari materi pelajaran tersebut dan menghubungkan dengan kehidupannya. Hal ini dapat terjadi dengan adanya interaksi, baik interaksi antar gurusiswa, guru-materi, siswa-siswa, maupun siswamateri. Namun interaksi tidak akan terjadi apabila material-material yang dilibatkan dalam pembelajaran adalah sesuatu yang belum dikenali oleh siswa. Satu hal yang menjamin bahwa material tersebut tidaklah asing adalah material-material yang berasal dari budaya para siswa itu sendiri.

Menurut Minstrell (dalam Wena, 2014: 39) mengatakan bahwa untuk meningkatkan pemahaman pada diri siswa, guru harus mampu mengaitkan pengalaman keseharian siswa atau konsep-konsep yang telah ada dalam benak siswa dengan isi pembelajaran yang akan dibahas. Dengan demikian, siswa dapat berusaha memahami masalah, mencari hubungan-hubungan, membuat model matematika, dan menggunakan pengetahuan yang dimiliki sebelumnya untuk memecahkan masalah tersebut.

Bishop (Tandililing, 2013: 194) dalam kaitannya dengan budaya perilaku manusia yaitu manusia di manapun dan sepanjang waktu telah menggunakan matematika. Biasanya, matematika dapat diamati dalam enam perilaku universal berikut: menghitung, mengukur, menemukan, merancang, menjelaskan, dan bermain. Perilaku ini mencerminkan budaya 
orang-orang yang melakukan hal tersebut dan mau tidak mau dipengaruhi oleh nilai-nilai yang dipegang oleh budaya itu. Nilai-nilai budaya dapat diintegrasikan kedalam matematika sekolah merupakan cara mudah untuk membuat siswa merasa nyaman dan memahami konsep matematika dengan baik. Hal ini sejalan dengan Hiebert \& Capenter (Tandililing, 2013: 193) mengingatkan kepada semua pihak bahwa pengajaran matematika di sekolah dan matematika yang ditemukan anak dalam kehidupan sehari-hari sangat berbeda. Oleh sebab itu pembelajaran matematika sangat perlu memberikan muatan atau menjembatani antara matematika dalam dunia sehari-hari yang berbasis pada budaya lokal dengan matematika sekolah.

Pengintegrasian budaya kedalam pembelajaran matematika di dukung oleh pemerintah melalui otonomi daerah. Kartasasmita (Depdiknas, 2007:4) mengatakan bahwa otonomi daerah akan menuntut agar kurikulum matematika dan pelaksanaannya di satu daerah menyerap ciri-ciri dan praktek budaya dan kehidupan masyarakatnya. Pelaksanaan matematika yang berbasis budaya akan menciptakan interaksi dan komunikasi dengan orang lain. Hal ini sejalan dengan Bishop (Tandililing, 2013:2) yang mengatakan bahwa matematika merupakan suatu bentuk budaya. Matematika sebagai bentuk budaya, sesungguhnya telah terintegrasi pada seluruh aspek kehidupan masyarakat dimanapun berada. Selanjutnya Pinxten (Tandililing, 2013:194) menyatakan bahwa pada hakekatnya matematika merupakan teknologi simbolis yang tumbuh pada keterampilan atau aktivitas lingkungan yang bersifat budaya. Pendapat tersebut didukung oleh Bishop, yang mengatakan terdapat enam aktivitas dasar matematika yang terdapat pada budaya, yaitu menghitung, menempatkan, mengukur, merancang, memainkan, dan menjelaskan. Dengan demikian matematika seseorang dipengaruhi oleh latar budayanya, karena yang mereka lakukan berdasarkan apa yang mereka lihat dan rasakan sehingga mampu bersosialisasi dan berkomunikasi dalam konteks matematika dengan teman lainnya.

\section{Keefektifan}

Tingkatan keefektifan dari perangkat pembelajaran ditinjau dari kemajuan belajar, pemahaman, dan peningkatan kemampuan pemecahan masalah siswa. Reiguluth (dalam
Rochmad, 2012:70) menyatakan bahwa aspek yang paling penting dalam keefektifan adalah adalah untuk mengetahui tingkat atau derajat penerapan teori, atau model dalam suatu situasi tertentu. Menurut Slavin (2006: 277) bahwa keefektivan pembelajaran terdiri dari empat indikator, yaitu kualitas pembelajaran (quality of instruction), kesesuaian tingkat pembelajaran (appropriate level of instruction), insentif (incentive), dan waktu (time).

Masalah yang akan diteliti dalam penelitian ini dapat dirumuskan sebagai berikut: (1) Apakah pengembangan media interaktif berbasis budaya dalam pembelajaran matematika layak digunakan ?; dan (2) Apakah pengembangan media interaktif berbasis budaya dalam pembelajaran matematika ini efektif digunakan?

\section{METODE}

Lokasi penelitian ini dilaksanakan di SMP N 2 Indra Makmu, Kecamatan Indra Makmu, tepatnya di Kabupaten Aceh Timur. Kecamatan Indra Makmu merupakan lokasi terpencil.

Model pengembangan yang akan digunakan untuk mengembangkan perangkat media pembelajaran dalam penelitian ini adalah model Thiagarajan dkk. yang dikenal dengan Four-D Models (Model 4D). Model 4D dipilih karena sistematis dan cocok untuk mengembangkan perangkat media pembelajaran. Seperti kata Reynolds (dalam Rochmad: 2012: 61) "bahwa model Four-D tersebut dapat dijadikan sumber ide dan prosedur pengembangan untuk mengembangkan perangkat media pembelajaran dan penyebarannya (dissemination) pada bidang lain".

Model pengembangan 4D secara umum terdiri dari 4 tahap, yaitu: (1) tahap define (pendefinisian), bertujuan untuk menentukan dan mendefinisikan kebutuhan pembelajaran; (2) tahap design (perancangan), yaitu perancangan prototype perangkat pembelajaran; (3) tahap develop (pengembangan), bertujuan untuk menghasilkan perangkat media pembelajaran; (4) tahap diseeminate (penyebaran), yaitu tahap penggunaan perangkat media pembelajaran yang dikembangkan (Trianto, 2011: 177).

\section{Teknik Analisis Data}

Analisis data dalam penelitian ini menggunakan analisis deskriptif kuantitatif. Teknik deskriptif (Sugiono, 2009) adalah 
statistik yang digunakan untuk menganalisis data dengan cara menggambar data yang telah terkumpul sebagaimana adanya tanpa bermaksud membuat kesimpulan yang berlaku untuk umum atau generalisasi. Semua data yang terkumpul dianalisis menggunakan teknik statistic deskriptif yang secara kuantitatif dipisahkan menurut kategori untuk mempertajam penilaian dalam menarik kesimpulan. Data kualitatif yang berupa pernyataan sangat kurang baik, kurang baik, sedang, baik dan sangat baik diubah menjadi data kuantitatif dengan skala nilai 1 sampai 5 . Hasilnya dirata-rata dan digunakan untuk menilai kualitas produk pembelajaran. Criteria produk akan dikonversikan menjadi nilai dengan skala lima menggunakan skala Likert yang dianalisis secara deskriptif persentase dengan rumus sebagai berikut (Sugiono, 2009).

Dengan kriteria penilaian seperti yang tertulis pada Tabel berikut ini:

Tabel 1. Kriteria Penilaian (Sugiono,2009)

\begin{tabular}{|c|c|c|}
\hline Nilai & Kriteria & Skor \\
\hline A & Sangat baik & 5 \\
\hline B & Baik & 4 \\
\hline C & Sedang & 3 \\
\hline D & Kurang baik & 2 \\
\hline E & Sangat kurang baik & 1 \\
\hline
\end{tabular}

Kemudian data dianalisis dengan menggunakan statistic deskriptif (skor rata-rata dan persentase), yaitu menhitung persentase indicator dari setiap kategori pada media pembelajaran yang telah dikembangkan, seperti berikut ini :

Skor Empiris $=\frac{\text { jumlah skor yang diperoleh }}{\text { jumlah skor ideal seluruh item }} \times 100 \%$
Rumus diatas akan menghasilkan perhitungan angka dalam bentuk persen. Klasifikasi skor lalu diubah menjadi klasifikasi dalam bentuk persentase, selanjutnya ditafsirkan dengan kalimat bersifat kualitatif yang tercantum pada tabel berikut ini :

Tabel.2. persentase kriteria kesesuaian indikator

\begin{tabular}{|c|l|c|c|}
\hline Nilai & \multicolumn{1}{|c|}{ Kriteria } & Interval persentase & Keterangan \\
\hline A & Sangat baik & $85 \% \leq \mathrm{X} \leq 100 \%$ & Tidak perlu Direvisi \\
\hline B & Baik & $75 \% \leq \mathrm{X} \leq 84 \%$ & Tidak perlu Direvisi \\
\hline C & Sedang & $65 \% \leq \mathrm{X} \leq 74 \%$ & Direvisi \\
\hline D & Kurang baik & $55 \% \leq \mathrm{X} \leq 64 \%$ & Direvisi \\
\hline E & Sangat kurang baik & $0 \% \leq \mathrm{X} \leq 54 \%$ & Direvisi \\
\hline
\end{tabular}

( Sudjana, 2005)

Sedangkan dalam perhitungan tingkat kelayakan pada media pembelajaran penilaian adalah seperti pada tabel berikut ini :

Tabel.3. Kriteria kelayakan instrument Penilaian

\begin{tabular}{|c|l|c|}
\hline Nilai & Tingkat Kelayakan & Skor \\
\hline 1 & Tidak Layak & $<65 \%$ \\
\hline 2 & Kurang Layak & $65 \%-74 \%$ \\
\hline 3 & Layak & $75 \%-84 \%$ \\
\hline 4 & Sangat Layak & $85 \%-100 \%$ \\
\hline
\end{tabular}

( Purwanto, 2009)

\section{HASIL DAN PEMBAHASAN Deskripsi Data Hasil Uji Coba}

Berdasarkan validasi produk yang telah dilakukan kepada para ahli, maka Multimedia Interaktif berbasis budaya pada pembelajaran
Matematika, memiliki status layak digunakan dalam pemebalajaran. Selanjutnya dilakukan tahap Ujicoba yang dilakukan pada 3 tahap yaitu: (a) uji coba perorangan, (b) uji coba 
kelompok kecil, (c) uji coba lapangan (kelompok besar).

a. Data Hasil Ujicoba Perorangan

Uji coba perorangan dilakukan di SMP

Negeri 2 Indra Makmu. Uji coba perorangan dilakukan kepada 3 orang siswa Kelas VII, siswa tersebut terdiri dari kriteria 1 orang siswa prestasi tinggi, 1 orang siswa prestasi sedang, 1 orang siswa prestasi rendah. Tujuan dari ujicoba perorangan ini adalah untuk mengidentifikasi kekurangan produk setelah ditinnjau oleh para ahli. Penilaian dan masukan ini meliputi penyajian produk pembelajaran, yang terdiri dari aspek tampilan pembelajaran, penyajian materi, dan aspek manfaat pada multimedia interaktif berbasis budaya pada pembelajaran matematika. Hasil ujicoba berupa skor penilaian terhadap multimedia interaktif berbasis budaya, pada ujicoba perorangan pada aspek tampilan dapat dilihat pada tabel sebagai berikut :

Tabel.4. Skor Penilaian Multimedia Interaktif berbasis Budaya Ujicoba Perorangan

\begin{tabular}{|c|c|c|c|c|c|c|c|}
\hline \multirow[b]{2}{*}{ No } & \multirow[b]{2}{*}{ Indikator } & \multicolumn{3}{|c|}{ Responden } & \multirow{2}{*}{$\begin{array}{l}\text { Jumlah } \\
\text { skor }\end{array}$} & \multirow[b]{2}{*}{$\%$} & \multirow[b]{2}{*}{ Kriteria } \\
\hline & & 1 & 2 & 3 & & & \\
\hline \multicolumn{8}{|c|}{ Aspek Tampilan } \\
\hline 1 & $\begin{array}{l}\text { Tampilan awal multimedia interaktif } \\
\text { menarik }\end{array}$ & 5 & 4 & 5 & 14 & $93 \%$ & Sangat Baik \\
\hline 2 & $\begin{array}{l}\text { Petunjuk penggunaan multimedia } \\
\text { interaktif }\end{array}$ & 4 & 4 & 5 & 13 & $87 \%$ & Sangat Baik \\
\hline 3 & Kemudahan dalam pengoperasian & 4 & 5 & 5 & 14 & $93 \%$ & Sangat Baik \\
\hline 4 & Keterangan pada setiap icon & 5 & 4 & 4 & 13 & $87 \%$ & Sangat Baik \\
\hline 5 & $\begin{array}{l}\text { Pencantuman kompetensi inti dan } \\
\text { kompetensi dasar pada multimedia }\end{array}$ & 5 & 5 & 4 & 14 & $93 \%$ & Sangat Baik \\
\hline 6 & Background sesuai dengan materi & 5 & 4 & 4 & 13 & $87 \%$ & Sangat Baik \\
\hline \multicolumn{6}{|c|}{ Rata - Rata } & $90 \%$ & Sangat Baik \\
\hline \multicolumn{8}{|c|}{ Aspek Penyajian } \\
\hline 1 & $\begin{array}{l}\text { Multimedia menjelaskan konsep secara } \\
\text { lengkap }\end{array}$ & 5 & 4 & 4 & 13 & $87 \%$ & Sangat Baik \\
\hline 2 & $\begin{array}{l}\text { Multimedia interaktif menyajikan gambar, } \\
\text { animasi, serta video sesuai dengan materi }\end{array}$ & 5 & 5 & 4 & 14 & $93 \%$ & Sangat Baik \\
\hline 3 & $\begin{array}{lcc}\begin{array}{l}\text { Multimedia } \\
\text { menyelesaikan }\end{array} & \text { interaktif } & \text { dapat } \\
\text { pembelajaran } & & \\
\text { pemalah-masalah } & \text { dalam } \\
\end{array}$ & 4 & 5 & 4 & 13 & $87 \%$ & Sangat Baik \\
\hline 4 & $\begin{array}{l}\text { Multimedia dapat digunakan secara } \\
\text { individu atau kelompok }\end{array}$ & 4 & 5 & 4 & 13 & $87 \%$ & Sangat Baik \\
\hline 5 & $\begin{array}{l}\text { Materi yang disajikan dalam multimedia } \\
\text { interaktif disajikan secara bertahap }\end{array}$ & 5 & 4 & 4 & 13 & $87 \%$ & Sangat Baik \\
\hline 6 & $\begin{array}{l}\text { Bahasa yang digunakan dalam multimedia } \\
\text { interaktif mudah dipahami }\end{array}$ & 5 & 5 & 4 & 14 & $93 \%$ & Sangat Baik \\
\hline 7 & $\begin{array}{l}\text { Latihan dalam multimedia membantu } \\
\text { untuk mengevaluasi secara individu }\end{array}$ & 4 & 5 & 4 & 13 & $87 \%$ & Sangat Baik \\
\hline \multicolumn{6}{|c|}{ Rata - Rata } & $\mathbf{8 8 \%}$ & Sangat Baik \\
\hline \multicolumn{8}{|c|}{ Aspek Mafaat } \\
\hline 1 & $\begin{array}{l}\text { Saya dapat memahami materi PLSV } \\
\text { dengan menggunakan } \\
\text { interaktfi berbasis budaya }\end{array}$ & 5 & 4 & 5 & 14 & $93 \%$ & Sangat Baik \\
\hline 2 & $\begin{array}{l}\text { Saya merasa lebih mudah belajar } \\
\text { menggunakan multimedia interaktif }\end{array}$ & 4 & 5 & 4 & 13 & $87 \%$ & Sangat Baik \\
\hline 3 & $\begin{array}{l}\text { Saya lebih tertarik dalam belajar PLSV } \\
\text { menggunakan multimedia interaktif } \\
\text { berbasis budaya }\end{array}$ & 4 & 4 & 5 & 13 & $87 \%$ & Sangat Baik \\
\hline \multicolumn{5}{|c|}{ Rata - Rata } & & $89 \%$ & Sangat Baik \\
\hline
\end{tabular}


Tabel menunjukkan tanggapan 3 orang siswa pada uji perorangan di kelas VII SMP Negeri 2 Indra Makmu terhadap multimedia interaktif berbasis budaya secara keseluruhan dinyatakan dalam kriteria "Sangat Baik"

Tabel 5. Rangkuman Penilaian Multimedia Interaktif berbasis budaya pada Pembelajaran Matematika Pada Ujicoba Perorangan

\begin{tabular}{|c|c|c|c|}
\hline No & $\begin{array}{c}\text { Aspek } \\
\text { Penilaian }\end{array}$ & $\%$ & Kriteria \\
\hline $\mathbf{1}$ & Tampilan & $90 \%$ & Sangat Baik \\
\hline $\mathbf{2}$ & Penyajian & $88 \%$ & Sangat Baik \\
\hline $\mathbf{3}$ & Manfaat & $89 \%$ & Sangat Baik \\
\hline \multicolumn{2}{|c|}{ Rata - rata } & $\mathbf{8 9 \%}$ & Sangat Baik \\
\hline
\end{tabular}

Berdasarkan uraian dari tabel dapat disimpulkan bahwa penilaian Multimedia Interaktif berbasis budaya pada pembelajaran matematika dari hasil ujicoba perorangan mendapatkan total persentase skor sebesar 89\%, yakni dapat di kategorikan "Sangat Baik". Tingkat kriteria penilaian dapat dilihat pada tabel berikut:
Tabel. 6. Kriteria Penilaian Multimedia Interaktif

\begin{tabular}{|c|l|c|}
\hline Nilai & \multicolumn{1}{|c|}{ Kriteria } & Interval persentase \\
\hline A & Sangat baik & $85 \% \leq \mathrm{X} \leq 100 \%$ \\
\hline B & Baik & $75 \% \leq X \leq 84 \%$ \\
\hline C & Sedang & $65 \% \leq X \leq 74 \%$ \\
\hline D & Kurang baik & $55 \% \leq X \leq 64 \%$ \\
\hline E & $\begin{array}{l}\text { Sangat } \\
\text { kurang baik }\end{array}$ & $0 \% \leq X \leq 54 \%$ \\
\hline
\end{tabular}

b. Data Hasil Ujicoba Kelompok Kecil

Ujicoba kelompok kecil dilakukan di SMP Negeri 2 Indra Makmu. Ujicoba kelompok dilakukan kepada 6 orang siswa Kelas VII, yang siswa tersebut terdiri dari kriteria 2 orang siswa prestasi tinggi, 2 orang siswa prestasi sedang, 2 orang siswa prestasi rendah. Tujuan dari ujicoba kelompok kecil ini adalah untuk mengidentifikasi kekurangan produk. Ujicoba kelompok kecil ini dilaksanakan juga sebagai pengalaman sebelum produk di ujicoba lapangan. Data hasil ujicoba kelompok kecil dapat dilihat pada tabel berikut :

Tabel 7. Skor Penilaian Multimedia Interaktif Berbasis Budaya Ujicoba Kelompok Kecil

\begin{tabular}{|l|c|c|c|c|c|}
\hline \multirow{2}{*}{$\begin{array}{c}\text { Aspek } \\
\text { Penilaian }\end{array}$} & \multicolumn{3}{|c|}{$\begin{array}{c}\text { Persentasi Rata-rata skor } \\
\text { Responden/Tingkat Prestasi }\end{array}$} & \multirow{2}{*}{ Rata -Rata } & \multirow{2}{*}{ Kriteria } \\
\cline { 2 - 6 } & Tinggi & Sedang & Rendah & & \\
\hline Tampilan & $86,6 \%$ & $88,3 \%$ & $88,3 \%$ & $87,7 \%$ & Sangat Baik \\
\hline Penyajian & $88,5 \%$ & $90 \%$ & $80 \%$ & $86,2 \%$ & Sangat Baik \\
\hline Manfaat & $82,5 \%$ & $90 \%$ & $82,5 \%$ & $85 \%$ & Sangat Baik \\
\hline Rata - rata & $\mathbf{8 5 , 9 \%}$ & $\mathbf{8 9 , 4} \%$ & $\mathbf{8 3 , 6 \%}$ & & \\
\hline \multicolumn{7}{|c|}{ Rata - rata Total } & $\mathbf{8 6 , 3 \%}$ & Sangat Baik \\
\hline
\end{tabular}

Berdasarkan uraian dari tabel. 27 dapat disimpulkan bahwa penilaian Multimedia Interaktif berbasis budaya pada pembelajaran Matematika dari hasil ujicoba kelompok kecil mendapatkan total persentase skor sebesar 86, 3\%, dapat di kategorikan "Sangat Baik". Tingkat kriteria penilaian dapat dilihat pada tabel berikut:

Tabel. 8. Kriteria Penilaian Multimedia Interaktif

\begin{tabular}{|c|l|c|}
\hline Nilai & \multicolumn{1}{|c|}{ Kriteria } & Interval persentase \\
\hline A & Sangat baik & $85 \% \leq \mathrm{X} \leq 100 \%$ \\
\hline B & Baik & $75 \% \leq \mathrm{X} \leq 84 \%$ \\
\hline C & Sedang & $65 \% \leq \mathrm{X} \leq 74 \%$ \\
\hline D & Kurang baik & $55 \% \leq \mathrm{X} \leq 64 \%$ \\
\hline E & Sangat kurang baik & $0 \% \leq \mathrm{X} \leq 54 \%$ \\
\hline
\end{tabular}


c. Data Hasil Ujicoba Tahap Ujicoba
Lapangan
Ujicoba lapangan dilakukan di SMP Negeri 2 Indra Makmu. Ujicoba lapangan dilakukan kepada 36 orang siswa Kelas VII. Ujicoba lapangan menghasilkan data data yang nantinya akan mengukur efektifitas produk yang dikembangkan, serta mengetahui bagaimana manfaat produk.

Adapun data hasil uji coba lapangan oleh siswa pada setiap aspeknya dapat dilihat pada tabel berikut :

Tabel. 9. Skor Penilaian Multimedia Interaktif berbasis Budaya Ujicoba Lapangan

\begin{tabular}{|l|c|c|}
\hline \multicolumn{1}{|c|}{$\begin{array}{c}\text { Aspek } \\
\text { Penilaian }\end{array}$} & $\begin{array}{c}\text { Persentasi } \\
\text { Rata-rata } \\
\text { Skor } \\
\text { Responden }\end{array}$ & Kriteria \\
\hline Aspek Tampilan & $82 \%$ & Sangat Baik \\
\hline Aspek Penyajian & $80 \%$ & Sangat Baik \\
\hline Aspek Manfaat & $81 \%$ & Sangat Baik \\
\hline Rata - rata & \multicolumn{2}{|r|}{ Sangat Baik } \\
\hline
\end{tabular}

Kesimpulan hasil penilaian dan tanggapan uji coba lapangan dari 36 orang siswa keseluruhan maka disimpulkan bahwa persentase nilai rata - rata dari setiap aspek penilaiannya adalah $\mathbf{8 1 \%}$. Dimana jika rentang berada pada skor $81 \% \leq \mathrm{X} \leq 100 \%$ maka kecenderungan hasil uji coba lapangan dinyatakan kategori "Layak".

\section{Analisis Data Hasil Validasi Kelayakan Multimedia oleh Ahli}

Pelaksanaan validasi telah dilakukan menggunakan instrument angket dengan beberapa indicator penilaian. Selanjutnya setelah setiap indicator penilaian dalam angket produk yang dikembangkan telah diberi nilai dan skor rata-rata oleh masing-masing oleh para ahli, maka kemudian hasil tersebut dianalisis untuk menentukan layak tidaknya produk yang dikembangakan untuk diuji cobakan pada tahap selanjutnya.

Adapun persentase rata-rata dari hasil penilaian para ahli yaitu ahli materi, ahli desain, dan ahli media pembelajaran dapat dilihat pada table berikut :

Tabel. 10. persentase rata-rata hasil Penilaian Kelayakan Multimedia Interaktif Berbasis Budaya Pada pembelajaran Matematika

\begin{tabular}{|c|l|c|c|}
\hline No & Para Ahli & $\mathbf{\%}$ & Kriteria \\
\hline $\mathbf{1}$ & $\begin{array}{l}\text { Materi } \\
\text { Pembelajaran }\end{array}$ & $86 \%$ & Sangat Baik \\
\hline $\mathbf{2}$ & $\begin{array}{l}\text { Desain } \\
\text { Pembelajaran }\end{array}$ & $85 \%$ & Sangat Baik \\
\hline $\mathbf{3}$ & $\begin{array}{l}\text { Media } \\
\text { Pembelajaran }\end{array}$ & $89 \%$ & Sangat Baik \\
\hline \multicolumn{2}{|c|}{ Rata - rata } & $\mathbf{8 7 \%}$ & Sangat Baik \\
\hline
\end{tabular}

Berdasarkan table diatas, hasil validasi para ahli yaitu ahli materi, ahli desain dan ahli media pembelajaran secara keseluruhan menunjukkan tingkat validasi $87 \%$ terhadap produk yang di kembangkan, yang berarti termasuk kategori sangat layak secara keseluruhan. Hasil validasi ini juga menunjukkan bahwa multi media interaktif berbasis budaya dapat memenuhi kebutuhan pembelajaran dan sangat layak untuk diuji coba menurut penilaian para ahli. Berikut diagram rata-rata hasil penilian para ahli.

Penilaian para ahli menunjukkan bahwa multimedia interaktif berbasis budaya pada pembelajaran matematika dinyatakan layak untuk diuji cobakan kepada siswa dengan catatan revisi pada beberapa bagian. Adapun hasil analisa dari beberapa revisi yang dikemukakan oleh para ahli diuraikan sebagai berikut :

1) Ditambahakannya video animasi tentang nilai-nilai budaya

2) Audio music latar dan video trabble

3) Agar bahasa yang digunakan lebih sederhana lagi

4) Memberikan tombol fungsi untuk mematikan suara pada music latar

5) Membuat cover/ judul multimedia

6) Perumusan Kompetensi dasar dengan Kata Operasional

7) Alur media harus berdasarkan startegi pembelajaran

Revisi pertama dilakukan setelah selesai validasi produk oleh para ahli serangkaian revisi produk pada tahap ini dilaksanakan berdasarkan atas saran dan masukan dari para ahli sebagai validator di antaranya ahli materi, desain, dan media pembelajaran. Hasil validasi para ahli menunjukkan bahwa ada beberapa hal yang perlu diperbaiki pada produk yang dikembangkan. Adapun hal-hal tersebut dapat dilihat pada table berikut : 
Tabel. 11. Hasil revisi Multimedia Interaktif berbasis budaya pada Pembelajaran Matematika

\begin{tabular}{|l|l|l|}
\hline No & \multicolumn{1}{|c|}{ Sebelum Perbaikan } & \multicolumn{1}{c|}{ Sesudah Perbaikan } \\
\hline 1 & $\begin{array}{l}\text { Tidak adanya video tentang nilai-nilai } \\
\text { budaya }\end{array}$ & $\begin{array}{l}\text { Terdapat video tentang animasi dan } \\
\text { dokumentasi tentang nilai-nilai budaya }\end{array}$ \\
\hline 2 & $\begin{array}{l}\text { Audio Musik Latar dengan audio video } \\
\text { beradu (Trubble) }\end{array}$ & $\begin{array}{l}\text { Saat memutar video tidak ada lagi suara } \\
\text { music latar }\end{array}$ \\
\hline 3 & $\begin{array}{l}\text { Bahasa yang digunakan relative sulit } \\
\text { dipahami (kurang sederhana) }\end{array}$ & $\begin{array}{l}\text { Bahasa yang digunakan lebih disederhanakan } \\
\text { lagi agar mudah dipahami }\end{array}$ \\
\hline 4 & $\begin{array}{l}\text { Musik Latar tidak bisa dimatikan jika user } \\
\text { tidak dengan music latar }\end{array}$ & $\begin{array}{l}\text { Music latar sudah dapat di off kan jika user } \\
\text { tidak mau mendengar music latar }\end{array}$ \\
\hline 5 & Tidak terdapat cover/ judul multimedia & Terdapat cover/judul multimedia \\
\hline 6 & $\begin{array}{l}\text { Perumusan kompetensi dasar belum dengan } \\
\text { kata operasional }\end{array}$ & $\begin{array}{l}\text { Kompetensi dasar telah dirububah } \\
\text { menggunakan kata kerja opersional }\end{array}$ \\
\hline 7 & $\begin{array}{l}\text { Alur media belum sesuai dengan strategi } \\
\text { pembelajaran }\end{array}$ & $\begin{array}{l}\text { Alur media sudah sesuai dengan strategi } \\
\text { pembelajaran }\end{array}$ \\
\hline
\end{tabular}

\section{Analisis Hasil uji coba Perseorangan dan kelompok kecil}

Hasil analasis data uji perorangan pada setiap aspek penilaian secara keseluruhan ditentukan oleh skor rata rata kategorinya masing-masing. Hasil penilaian tersebut kemudian dianalisis untuk menentukan kekurangan kekurangan produk multimedia interaktif. Persentase rata-rata hasil uji coba perorangan yang dilakukan di SMP Negeri 2 Indra Makmu diuraikan pada tabel berikut :

Tabel. 12 Persentase Rata-rata Hasil Penilaian Terhadap Multimedia Interaktif berbasis Budaya Pada Ujicoba Perorangan

\begin{tabular}{|c|l|c|l|}
\hline No & \multicolumn{1}{|c|}{ Aspek } & \% & \multicolumn{1}{|c|}{ Kriteria } \\
\hline $\mathbf{1}$ & Tampilan & $90 \%$ & Sangat Baik \\
\hline $\mathbf{2}$ & Penyajian & $88 \%$ & Sangat Baik \\
\hline $\mathbf{3}$ & Manfaat & $89 \%$ & Sangat Baik \\
\hline \multicolumn{2}{|c|}{ Rata - rata } & $\mathbf{8 9 \%}$ & Sangat Baik \\
\hline
\end{tabular}

Tabel diatas menunjukkan persentase rata rata hasil penilaian pada ujicoba perorangan kepada 3 orang siswa kelas VII SMP Negeri 2 Indra Makmu pada aspek tampilan multimedia interaktif terdapat $90 \%$ termasuk kategori sangat baik, pada aspek kelayakan penyajian materi pembelajaran sebesar $88 \%$ termasuk dalam kategori sangat baik, dan pada aspek manfaat sebesar 89\% masuk dalam kategori sangat baik.

Hasil penilaian terhadap multimedia interaktif pada ujicoba perorangan yang dilakukan kepada 3 orang siswa, menunjuan bahwa produk yang dikembangkan layak digunakan dan tidak ada saran dan perbaikan yang disampaikan pada ujicoba perorangan, sehingga kegiatan pengembangan dilanjutkan pada ujicoba kelompok kecil tanpa ada revisi.

Hasil analasis data ujicoba kelompok kecil pada setiap aspek penilaian secara keseluruhan ditentukan oleh skor rata rata kategorinya masing-masing. Persentase ratarata hasil uji coba perorangan yang dilakukan di kelas VII SMP Negeri 2 Indra Makmu diuraikan pada tabel berikut

Tabel. 13. Persentase Rata-rata Hasil Penilaian Terhadap Multimedia Interaktif berbasis Budaya Pada Ujicoba kelompok kecil

\begin{tabular}{|c|l|c|l|}
\hline No & \multicolumn{1}{|c|}{ Aspek } & \% & \multicolumn{1}{|c|}{ Kriteria } \\
\hline $\mathbf{1}$ & Tampilan & $87,7 \%$ & Sangat Baik \\
\hline $\mathbf{2}$ & Penyajian & $86,2 \%$ & Sangat Baik \\
\hline $\mathbf{3}$ & Manfaat & $85 \%$ & Sangat Baik \\
\hline \multicolumn{2}{|c|}{ Rata - rata } & $\mathbf{8 6 , 3 \%}$ & $\begin{array}{l}\text { Sangat } \\
\text { Baik }\end{array}$ \\
\hline
\end{tabular}

Tabel diatas menunjukkan persentase rata rata hasil penilaian pada ujicoba kelompok kecil kepada 6 orang siswa kelas VII SMP Negeri 2 Indra Makmu pada aspek tampilan multimedia interaktif terdapat $87,7 \%$ termasuk kategori sangat baik, pada aspek kelayakan penyajian materi pembelajaran sebesar $86,2 \%$ termasuk dalam kategori sangat baik, dan pada aspek manfaat sebesar $85 \%$ masuk dalam kategori sangat baik.

Hasil penilaian terhadap multimedia interaktif pada ujicoba kelompok kecil yang dilakukan kepada 6 orang siswa, menunjuan 
bahwa produk yang dikembangkan layak digunakan dan tidak ada saran dan perbaikan yang disampaikan pada ujicoba perorangan, sehingga kegiatan pengembangan dilanjutkan pada ujicoba lapangan tanpa ada revisi.

\section{Analisis Hasil uji coba lapangan}

Hasil analasis data ujicoba lapangan pada setiap aspek penilaian secara keseluruhan ditentukan oleh skor rata rata kategorinya masing-masing. Persentase rata-rata hasil uji coba perorangan yang dilakukan di kelas VII SMP Negeri 2 Indra Makmu diuraikan pada tabel berikut :

Tabel. 14. Persentase Rata-rata Hasil Penilaian Terhadap Multimedia Interaktif berbasis Budaya Pada Ujicoba Lapangan

\begin{tabular}{|c|l|c|l|}
\hline No & Aspek & $\%$ & \multicolumn{1}{|c|}{ Kriteria } \\
\hline $\mathbf{1}$ & Tampilan & $82 \%$ & Sangat Baik \\
\hline $\mathbf{2}$ & Penyajian & $80 \%$ & Sangat Baik \\
\hline $\mathbf{3}$ & Manfaat & $81 \%$ & Sangat Baik \\
\hline \multicolumn{2}{|c|}{ Rata - rata } & $\mathbf{8 1 \%}$ & Sangat Baik \\
\hline
\end{tabular}

Tabel diatas menunjukkan persentase rata rata hasil penilaian pada ujicoba lapangan kepada 36 orang siswa kelas VII SMP Negeri 2 Indra Makmu pada aspek tampilan multimedia interaktif terdapat $82 \%$ termasuk kategori sangat baik, pada aspek penyajian materi pembelajaran sebesar $80 \%$ termasuk dalam kategori sangat baik, dan pada aspek manfaat sebesar $81 \%$ masuk dalam kategori sangat baik.

Hasil penilaian terhadap multimedia interaktif pada ujicoba lapangan yang dilakukan kepada siswa kelas VII SMP Negeri 2, secara umum dinyatakan sangat baik atau layak digunakan tidak ada saran dan perbaikan yang disampaikan pada ujicoba lapangan, sehingga kegiatan pengembangan dilanjutkan pada ujicoba kelompok kecil tanpa ada revisi.

\section{Deskripsi Tahap Penyebaran (Disseminate)}

Pengembangan perangkat pembelajaran mencapai tahap akhir dimana perangkat pembelajaran telah memperoleh penilaian positif dari para ahli dan melalui tes pengembangan.

\section{Deskripsi dan Analisis Efektivitas Perangkat Pembelajaran Berbasis Budaya yang dikembangkan}

Pengujian keefektifan multimedia dilakukan melalui tes hasil belajar terhadap kelas yang telah diberi perlakuan. Sebelum diberikan perlakuan, kelas tersebut diberikan pretes untuk mengukur kemampuan awal siswa, kemudian baru diberikan postes untuk mengetahui hasil belajar siswa.

Berdasarkan data yang diperoleh dari pretes dan postes dapat diketahui bahwa skor hasil belajar persamaan linear satu variabel dengan menggunaka multimedia interaktif diperoleh untuk prestes skor terendah 30 dan skor tertinggi 70, rata-rata skor 52,6 sedangkan untuk postes skor terendah 70 dan skor tertinggi 95, rata-rata skor 85 . Untuk melihat skor siswa digunakan kelas interval yaitu skor antara frekuensi absolut yaitu jumlah siswa yang memiliki skor hasil belajar, dan frekuensi relatif yaitu jumlah persen skor hasil belajar.

\section{Kelayakan dan Keefektifan Produk}

Hasil kelayakan multimedia interaktif berbasis budaya pada pembelajaran matematika dapat dilihat pada tabel dibawah ini :

Tabel. 16. Hasil Pengujian hasil Kelayakan Produk

\begin{tabular}{|c|c|c|c|c|}
\hline No & Tahap Pengujian & Hasil Pengujian & $\begin{array}{c}\text { Kriteria } \\
\text { Kelayakan }\end{array}$ & Kesimpulan \\
\hline 1 & Uji Ahli & $87 \%$ & Sangat Baik & \multirow{5}{*}{$\begin{array}{c}\text { Multimedia } \\
\text { pembelajaran } \\
\text { interaktif berbasis } \\
\text { budaya pada } \\
\text { pembelajaran } \\
\text { matematika sangat } \\
\text { layak digunakan di } \\
\text { SMP Negeri 2 } \\
\text { Indra Makmu }\end{array}$} \\
\hline 2 & Uji Perorangan & $89 \%$ & Sangat Baik & \\
\hline 3 & Uji Kelompok Kecil & $86,3 \%$ & Sangat Baik & \\
\hline 4 & Uji Lapangan & $81 \%$ & baik Baik & \\
\hline & Rata - Rata & $85,8 \%$ & Sangat Baik & \\
\hline
\end{tabular}




\subsection{Keefektifan Produk}

Herman (2012:3) menyebutkan bahwa kriteria efektif suatu pembelajaran apabila memenuhi 3 dan 4 kriteria keefektifan, yaitu: (1) ketercapaian hasil belajar yaitu minimal 80\% ketuntasan klasikal; (2) aktivitas siswa memenuhi kriteria toleransi waktu yang telah ditetapkan; (3) lebih dari 50\% siswa memberi respon positif terhadap perangkat pembelajaran yang dikembangkan. dan (4) kemampuan guru mengelola pembelajaran pada kategori "baik"

Berdasarkan uraian di atas, maka dalam penelitian ini perangkat pembelajaran dikatakan efektif merujuk pada pendapat Herman dan Mulyana yang disesuaikan dengan kebutuhan penelitian, yaitu: (1) $85 \%$ siswa tuntas secara klasikal; (2) aktivitas siswa memenuhi kriteria toleransi waktu yang telah ditetapkan; dan (3) Minimal $80 \%$ siswa memberi respon positif terhadap perangkat pembelajaran yang dikembangkan.

Hasil keefektifan multimedia interaktif berbasis budaya pada pembelajaran matematika dapat dilihat pada tabel dibawah ini :

Tabel. 17 Deskripsi Rata-rata Data Hasil Belajar PLSV

\begin{tabular}{|l|l|c|}
\hline No & \multicolumn{1}{|c|}{ Jenis Test } & $\begin{array}{c}\text { Rata - rata } \\
\text { skor }\end{array}$ \\
\hline 1 & Pretest & 52,6 \\
\hline 2 & Postest & 85 \\
\hline
\end{tabular}

Tabel. 18 Persentase Rata-rata Hasil Penilaian Terhadap Multimedia Interaktif berbasis Budaya Pada Ujicoba Lapangan

\begin{tabular}{|c|l|c|l|}
\hline No & Aspek & Persentase & Kriteria \\
\hline $\mathbf{1}$ & Tampilan & $82 \%$ & Sangat Baik \\
\hline $\mathbf{2}$ & Penyajian & $80 \%$ & Sangat Baik \\
\hline 3 & Manfaat & $81 \%$ & Sangat Baik \\
\hline \multicolumn{2}{|c|}{ Rata - rata } & $\mathbf{8 1 \%}$ & $\begin{array}{l}\text { Sangat } \\
\text { Baik }\end{array}$ \\
\hline
\end{tabular}

Dari data tabel diatas dapat disimpulkan bahwa adanya peningkatan hasil belajar dengan menggunakan multimedia interaktif berbasis budaya pada pembelajaran matematika. Serta sebanyak $81 \%$ siswa merespon positif terhadap multimedia interaktif berbasis budaya pada pembelajaran matematika. Oleh karena itu dapat disimpulkan multimedia interaktif berbasis budaya pada pembelajaran matematika sangat efektif.

\section{Penyebaran Produk}

Setelah melakukan menganalisis data hasil uji coba pada SMP negeri 2 Indra Makmu dengan hasil sangat efektif, kemudian tahap selanjutnya adalah penyebaran di sekolah sekolah lain pada penelitian ini peneliti menyebarkan di 4 (empat) sekolah lain yaitu : SMP Negeri 1 Julok (Aceh Timur); SMP Negeri 5 Lhokseumawe (Kota Lhokseumawe); SMP Negeri 1 Lhoksukon (Aceh Utara); dan SMP Negeri 2 Langsa (Kota Langsa) dan dari keempat sekolah tersebut dapat diperoleh data sebagai berikut :

Tabel. 19 Data Hasil Tahab Penyebaran di 4 (Empat) Sekolah

\begin{tabular}{|c|lr|c|c|}
\hline \multirow{2}{*}{ No } & \multicolumn{2}{|c|}{ Nama Sekolah } & \multicolumn{2}{c|}{ Rata-rata Skor } \\
\cline { 3 - 5 } & Pretes & $\begin{array}{c}\text { Post } \\
\text { Test }\end{array}$ \\
\hline $\mathbf{1}$ & $\begin{array}{l}\text { SMP Negeri 1 } \\
\text { Julok }\end{array}$ & 62,3 & 86 \\
\hline $\mathbf{2}$ & $\begin{array}{l}\text { SMP Negeri 5 } \\
\text { Lhokseumawe }\end{array}$ & 70 & 94,5 \\
\hline $\mathbf{3}$ & $\begin{array}{l}\text { SMP Negeri 1 } \\
\text { Lhoksukon }\end{array}$ & 57,3 & 86,7 \\
\hline $\mathbf{4}$ & $\begin{array}{l}\text { SMP Negeri 2 } \\
\text { Langs }\end{array}$ & 65 & 80,4 \\
\hline
\end{tabular}

Tabel. 20 Persentase Rata-rata Hasil Penilaian Terhadap Multimedia Interaktif berbasis Budaya Pada Ujicoba Lapangan

\section{a. SMP Negeri 1 Julok}

\begin{tabular}{|c|l|c|l|}
\hline No & Aspek & Persentase & \multicolumn{1}{|c|}{ Kriteria } \\
\hline $\mathbf{1}$ & Tampilan & $83 \%$ & Sangat Baik \\
\hline $\mathbf{2}$ & Penyajian & $85 \%$ & Sangat Baik \\
\hline 3 & Manfaat & $87 \%$ & Sangat Baik \\
\hline \multicolumn{2}{|c|}{ Rata - rata } & $\mathbf{8 5 \%}$ & $\begin{array}{l}\text { Sangat } \\
\text { Baik }\end{array}$ \\
\hline
\end{tabular}

b. SMP Negeri 5 Lhokseumawe

\begin{tabular}{|c|l|c|l|}
\hline No & Aspek & Persentase & Kriteria \\
\hline $\mathbf{1}$ & Tampilan & $79 \%$ & Baik \\
\hline $\mathbf{2}$ & Penyajian & $85 \%$ & Sangat Baik \\
\hline $\mathbf{3}$ & Manfaat & $81 \%$ & Sangat Baik \\
\hline \multicolumn{2}{|c|}{ Rata - rata } & $\mathbf{8 2} \%$ & $\begin{array}{l}\text { Sangat } \\
\text { Baik }\end{array}$ \\
\hline
\end{tabular}


c. SMP Negeri 1 Lhoksukon

\begin{tabular}{|c|l|c|l|}
\hline No & Aspek & Persentase & Kriteria \\
\hline $\mathbf{1}$ & Tampilan & $83,33 \%$ & Sangat Baik \\
\hline $\mathbf{2}$ & Penyajian & $87,77 \%$ & Sangat Baik \\
\hline $\mathbf{3}$ & Manfaat & $90 \%$ & Sangat Baik \\
\hline \multicolumn{2}{|c|}{ Rata - rata } & $\mathbf{8 7 , 0 3 \%}$ & $\begin{array}{l}\text { Sangat } \\
\text { Baik }\end{array}$ \\
\hline
\end{tabular}

\section{d. SMP Negeri 2 Langsa}

\begin{tabular}{|c|l|c|l|}
\hline No & Aspek & Persentase & Kriteria \\
\hline $\mathbf{1}$ & Tampilan & $84,33 \%$ & Sangat Baik \\
\hline $\mathbf{2}$ & Penyajian & $79,33 \%$ & Baik \\
\hline $\mathbf{3}$ & Manfaat & $77 \%$ & Baik \\
\hline \multicolumn{2}{|c|}{ Rata - rata } & $\mathbf{8 0 , 2 2}$ & $\begin{array}{l}\text { Sangat } \\
\text { Baik }\end{array}$ \\
\hline
\end{tabular}

\section{Pembahasan Hasil Penelitian}

Pada pengujian kelayakan multimedia interaktif ini melalui tiga tahap, dengan hasilnya masing-masing sebagai berikut :

a. Hasil penilaian kelayakan media pembelajaran interaktif oleh validator ahli dari segi aspek : (1) materi Pembelajaran 86\%; (2) desain Pembelajaran 85\% dan (3) media pembelajaran $89 \%$. Secara keseluruhan rata-rata penilaian oleh validator ahli terhadap multimedia interaktif berbasis budaya untuk pembelajaran matematika adalah sebesar 87\%. Sehingga, berdasarkan uji kelayakan oleh para ahli maka multimedia interaktif bebrbasis budaya pada pembelajaran matematika sangat layak digunakan.

b. Hasil penilaian kelayakan multimedia interaktif pada uji coba perorangan dari aspek : (1) Tampilan 90\%, (2) Penyajian $88 \%$, (3) manfaat $89 \%$. Secara keseluruhan, penilaian pada tahap uji coba perorangan terhadap multimedia interaktif berbasis budaya sebesar $89 \%$. Sehingga, berdasarkan uji coba kelayakan perorangan maka multimedia interaktif berbasis budaya pada pembelajaran matematika sangat layak digunakan.

c. Hasil penilaian kelayakan multimedia interaktif pada uji coba kelompok kecil dari aspek : (1) Tampilan 87,7\%, (2) Penyajian $86,2 \%$, (3) manfaat $85 \%$. Secara keseluruhan, penilaian pada tahap uji coba perorangan terhadap multimedia interaktif berbasis budaya sebesar $86,3 \%$. Sehingga, berdasarkan uji coba kelayakan kelompok kecil maka multimedia interaktif berbasis budaya pada pembelajaran matematika sangat layak digunakan

d. Hasil penilaian kelayakan multimedia interaktif pada uji lapangan dari aspek : (1) Tampilan 82\%, (2) Penyajian 80\%, (3) manfaat $81 \%$. Secara keseluruhan, penilaian pada tahap uji coba perorangan terhadap multimedia interaktif berbasis budaya sebesar $81 \%$. Sehingga, berdasarkan uji coba kelayakan kelompok kecil maka multimedia interaktif berbasis budaya pada pembelajaran matematika sangat layak digunakan

Setelah selesai melaksanakan uji kelayakan yang hasilnya menunjukkan bahwa multimedia interaktif pembelajaran telah sangat layak untuk digunakan, maka langkah selanjutnya adalah melakukan uji keefektifan tentang penggunaan multimedia interaktif berbasis budaya pada pembelajaran matematika di SMP Negeri 2 Indra Makmu. Hasil pengujian keefektifan multimedia interaktif berbasis budaya dapat dilihat pada table berikut :

Tabel. 21 Deskripsi Rata-rata Data Hasil Belajar PLSV

\begin{tabular}{|c|l|c|}
\hline No & \multicolumn{1}{|c|}{ Jenis Test } & $\begin{array}{c}\text { Rata }- \text { rata } \\
\text { skor }\end{array}$ \\
\hline 1 & Pretest & 52,6 \\
\hline 2 & Postest & 85 \\
\hline
\end{tabular}

Dari tabel diatas dapat disimpulkan bahwa terdapat peningkatan hasil belajar dari sebelum menggunakan multimedia interaktif berbasis budaya dengan sesudah belajar menggunakan multimedia interaktif berbasis budaya. Maka dapat ditarik kesimpulan adalah :

1. Adanya ketercapaian hasil belajar yaitu ketuntasan klasikal yaitu 85 .

2. Rata - rata $81 \%$ siswa memberikan respon positif terhadap multimedia interaktif berasis budaya pada pembelajaran matematika yang dikembangkan.

Setelah melakukan penelitian di SMP negeri 2 Indra makmu, peneliti menyebarkan produk ke 4 (empat) sekolah lain untuk melakukan uji efektifitas. Dan hasil adalah sebagai berikut : 
Tabel. 21 Deskripsi Rata-rata Data Hasil Pretes dan Postes

\begin{tabular}{|l|l|c|c|c|c|}
\hline \multirow{2}{*}{ No } & \multirow{2}{*}{ Nama Sekolah } & \multicolumn{3}{|c|}{ Rata-rata } & \multirow{2}{*}{ Kriteria } \\
\cline { 3 - 5 } & $\begin{array}{c}\text { Nilai } \\
\text { Pretes }\end{array}$ & $\begin{array}{c}\text { Nilai Post } \\
\text { Test }\end{array}$ & $\begin{array}{c}\text { \% Penilaian } \\
\text { Media }\end{array}$ & \\
\hline $\mathbf{1}$ & SMP Negeri 1 Julok & 62,3 & 86 & $85 \%$ & Sangat Baik \\
\hline $\mathbf{2}$ & SMP Negeri 5 Lhokseumawe & 70 & 94,5 & 82 & Sangat Baik \\
\hline $\mathbf{3}$ & SMP Negeri 1 Lhoksukon & 57,3 & 86,7 & 87,03 & Sangat Baik \\
\hline $\mathbf{4}$ & SMP Negeri 2 Langsa & 65 & 80,4 & 80,22 & Sangat Baik \\
\hline & Rata - Rata & 63,65 & 86,9 & 83,56 & \\
\hline
\end{tabular}

Dari data diatas, dapat ditarik kesimpulan bahwa terjadi kenaikan nilai dari tes awal (pretes) dengan tes akhir (posttest) serta hasil persentasi penilaian siswa terhadap media diatas $80 \%$ dengan kata lain memperoleh kriteria "sangat baik". Dengan demikian multimedia interaktif berbasis budaya pada pembelajaran matematika dapat dikategorikan sangat efektif. Kesimpulan tersebut disandarkan pada pendapat Herman (2012) yang menyebutkan bahwa keefektifan pembelajaran, yaitu : 1). $85 \%$ siswa tuntas secara kasikal. Ini dibuktikan dari hasil post test rata-rata siswa memperoleh nilai $86 \%$ pada penelitian ini 2). Aktivitas siswa memenuhi kriteria toleransi waktu yang telah ditetapkan. 3). Minimal $80 \%$ siswa meberikan respon positif. Ini dibuktikan dengan respon siswa terhadap media ini adalah sebesar $81 \%$. maka dapat disimpulkan bahwa multimedia interaktif berbasis budaya pada pembelajaran matematika dapat dikategorikan sangat efektif.

\section{PENUTUP}

Setelah melakukan proses atau tahapan pengembangan media interaktif berbasis budaya pembelajaran matematika ini dapat disimpulkan sebagai berikut:

Media interaktif berbasis budaya pada pembelajaran matematika layak digunakan.

Dari hasil data pengujian dilokasi penelitian serta disekolah penyebaran produk di dapatkan hasil yang menunjukkan bahwa Media interaktif berbasis budaya pada pembelajaran matematika ini sangat efektif digunakan.

\section{DAFTAR PUSTAKA}

D Ambrosio. (2006). The Program Ethnomathematics: A Theoretical Basis of the Dynamics of Intra-Cultural Encounters. The Journal of Mathematics and Culture ol6.hal.1-7.
Herman. (2012). Pengembangan Perangkat Pembelajaran Model Pengajaran Langsung untuk Mengajarkan Materi Kesetimbangan Benda Tegar. Jurnal Sainsdan Pendidikan Fisika, Jilid 8 Nomor 1.hal.1-11.

Rochmad. (2012). Desain Model Pengembangan Perangkat Pembelajaran. Jurnal Kreano. Volume 3 Nomor : 59-72 Sanjaya, W. (2012). Media Komunikasi Pembelajaran. Jakarta: Kencana Prenada Media Group ..(2014). Strategi Pembelajaran Berorientasi Standar Proses Pendidikan, Jakarta: Kencana Prenada Media Group.

Sani, R. A. (2013). InovasiPembelajaran. Jakarta: BumiAksara

Sugiono, (2009). Metode Penelitian Pendidikan Pendekatan Kualitatif, Kuantitatif, dan $R \& D$. Bandung : CV. Alfabeta

Tandililing, E. (2013). Pengembangan Pembelajaran Matematika Sekolah Dengan Pendekatan Etnomatematika Berbasis Budaya Lokal Sebagai Upaya Untuk Meningkatkan Kualitas Pembelajaran Matematika Di Sekolah. Makalah disampaikan pada Seminar Nasional Matematika dan Pendidikan Matematika: Penguatan Peran Matematika dan Pendidikan Matematika untuk Indonesia yang Lebih Baik, Yogyakarta: Tidak Diterbitkan

Trianto. (2011). Mendesain Model Pembelajaran Inovatif-Progresif. Jakarta: Kencana Prenada Media Group.

Wena, M. (2014). Strategi Pembelajaran Inovatif Kontemporer Suatu Tinjauan Konseptual Operasional. Jakarta: PT BumiAksara

Slavin, R. E. (2010). Cooperative Learning Teori, Riset dan Praktik. Bandung: Nusa Medan 